\title{
Authentic Leadership Principals' and Teachers' Commitment to Improve Work Discipline
}

\author{
Herlina \\ Universitas Pendidikan Indonesia \\ herlina.adpend@gmail.com \\ Aan Komariah \\ Universitas Pendidikan Indonesia \\ Aan_komariah@upi.edu
}

\author{
Abubakar \\ Universitas Pendidikan Indonesia \\ abubakar@upi.edu
}

\begin{abstract}
The quality of education in the education unit depends fully to the professionalism of teachers are professional, disciplined, diligent, moral teacher, to concentrate full time, and promote the quality. Instead of teachers who dogged laziness, lack of discipline, not conscious of time and relaxed lifestyle habits (whatever they are) will have an impact on the decline even failures in education. To improve work discipline the teacher is not only the government's task but the task of principals as leaders of institutions must also work to increase the commitment of teachers. The method used in this research is descriptive quantitative approach as for the sample of 166 teachers. The results showed that authentic leadership and significant positive effect on the working discipline in the amount of $22.6 \%$ and a work commitment of teachers positive and significant effect of $28.3 \%$, while authentic leadership and commitment of teachers working together influential and significant $35.7 \%$, Linear regression equation obtained authentic means higher leadership and commitment to the work of teachers, the higher also work discipline teacher in MI as the city of Cimahi.
\end{abstract}

Keywords-Authentic leadership, Teachers Work Commitment, Discipline Teacher Working

\section{INTRODUCTION}

One of the components and the spearhead of an education is the teacher. Teachers have a strategic role and mmenjadi the forefront in the implementation of education, teachers are people who are in the presence of students to transfer knowledge as well as to educate the students by example and guidance. Today the teacher's task is not only to educate in the classroom but must also do the things that are administrative in school. The task of the teacher is: Educating the center of gravity provide direction and motivation achievement of goals both short term and long term, Facilitate the achievement of ttujuan through learning experiences adequate, and foster aspects such as attitudes, values, and adjustment. [1]

Research suggests that the problems facing teachers today of the discipline factor is the teacher did not come on time, frequent violations by teachers to the duties and functions, the teachers teach not in accordance with the plans that have been made even less teachers to teach without the use planning. If this trend continues it will affect the quality of education itself. [2]

The quality of education in the education unit depends fully to the professionalism of teachers are professional, disciplined, diligent, moral teacher, to concentrate full time, and promote the quality. Instead of teachers who dogged laziness, lack of discipline, not conscious of time and relaxed lifestyle habits (whatever they are) will have an impact on the decline even failures in education. [3]

Maybe if other education personnel can not attend school for some time, but if a teacher is absent a few moments, then the process of education and learning can not walk properly. So that teachers should be able to cultivate and strengthen its commitment in schools. Based on the above explanation, encourage researchers studied more deeply about how much influence the Authentic Leadership and work commitment of teachers to work dsiplin teacher in MI as the city of Cimahi.

\section{RESEARCH METHODS}

The methodology in this study descriptive with quantitative approach as for the sample of 166 teachers in 20 schools in Cimahi.

\section{RESULT}

Labor discipline of teachers is one of the factors that can affect student achievement, in connection with the execution of the task or job that is charged to a person, the disciplinary role as the driving force of willingness and desire to work according to the measures or restrictions are set. [4] Discipline working according to Malay SP Hasibuan is the awareness and the willingness of a person to comply with all company rules and social norms that apply. Awareness in question is the attitude of someone who voluntarily comply with all regulations and are aware of the duties and tanggungj awabnya. Work discipline is defined when employees always come and go home on time. Labor discipline teachers is very important in order to support student achievement that the discipline of a teacher at work 
or in giving the lesson student achievement can be increased. [5]

MI teacher labor discipline as the city of Cimahi are in either category this means that teachers have been in compliance with the regulations, adherence to labor standards and work ethics. Job performance of teachers also responded very positively almost all three elements, namely timeliness, quality of work and quantity of work. Discipline is a tool used by managers to communicate with subordinates so that they are willing to change a behavior as well as an effort to raise awareness and the willingness of a person to comply with all company rules and social norms that apply. [6]

Adherence to the rules in the discipline of work is an important aspect though the field turns out there are some rules that have been violated as late arriving for no apparent reason, but work discipline is an important thing, which is one aspect of the power of the Human Resources (HR) can be reflected in the attitudes and behavior of discipline because the discipline has a profound impact on an organization to achieve success in the pursuit of the objectives planned. [7]

Working ethically meant that teachers should be able to work with the ethics and norms, because the teacher is a role model for his students, if teachers can not discipline themselves then sekolahlah the discipline to teachers in a way: making the rules clear work, discipline positive with a warning, giving time off, evaluating up to and including discharge. [8]

Teachers who have a good working discipline reflects a great responsibility towards their duties, thereby increasing the performance of the teacher. [9] The performance of a good teacher would make student achievement is increased, the learning process goes well and would increase school achievement.

In the teachings of Islam are many verses of the Qur'an and the Hadith which ordered the discipline in terms of adherence to prescribed rules, including a letter of An Nisa verse 59: which means: "who believe, obey Allah and obey the apostle and his and to Ulil Amri from (among) you ... "(An-Nisa: 59). Self-discipline in Islam is the faith is to do all his commandments without forced pronounced orally believe with your heart and do the deed. This discipline is characteristic of the pious in Islam.

MI school principals as the city of Cimahi been excellent in determining the direction of the school ranging from making the vision to the implementation of the vision as a common end to be achieved. a leader of authentic sets the basis for the belief transparently convey its attributes, values, aspirations, and a weakness for the followers, and by encouraging them to do the same. [10] The principal must be able to convince subordinates to have the same general purpose, encouraging group members to share common goals, values, and beliefs that authentic leadership should encourage teachers to share a common purpose, values and beliefs. [11]
With Islamic values mean authentic leader at the school is more directed to the leader on the basis of Islamic law. The survey results revealed that the highest indicators of leadership autentic is the goal, so the headmaster authentic is a leader who has a vision for the future is clearly in the words of Islam said Sidiq, which is really where a leader is always telling the truth. The Prophet always say everything in accordance with the truth that comes from God Almighty. as well as a leader or president we elected later, are expected to have these properties so that she too had thoughts, feelings, and the words were always consistent with his actions.

The commitment of teachers in schools is an important element of commitment even be used as a condition for holding a task or position offered. Teachers who have a strong commitment to be satisfied with their work environment and create harmony at school. When low, the professional commitment of teachers was low, while teachers with a high commitment profesionalis tend to have attitude and uphold the values of the organization in carrying out its work. [12]Leadership is also one that will help improve teachers' work commitment for the best way to motivate people to mmeberikan high commitment to the values of the organization is the leadership and engagement. [13]

To see the inside of a teacher's commitment must be seen in the effort and time they need to survive in the madrassas, because most of the teachers madrasah is nonPNS thus requiring high snagat commitment to stay afloat. Commitments in Islam as saying two creed sentence already promised and will be committed to run all the command and away from the ban.

Effect of authentic leadership to discipline teachers working relationships being this because influenced by the work discipline supervision and also exemplary leader and both are inherent in a leader authentic. To get a teacher who has a high work discipline and fostering cooperative oversight role that was built with the concept of democracy by the leadership of the teachers should be created properly. This will result in leadership roles need to be flexible or inflexible and self-awareness teacher who fully accept the rules that have been agreed. [14]

Labor discipline teachers must be supported by the leadership of the agency in this case the principal, good discipline that subservience to the regulations without any coercion from the leadership. [15] The head of the school is able to improve the discipline teacher is the leadership that is able to discipline themselves first so that. Basically discipline is of value investment and the authentic leadership becomes the spirit is a value so as to achieve common goals, effective leadership can be achieved through the development of credible and acceptable attitudes in the workplace as well as loved by his followers. [16]

The school principal as a person who has authentic leadership is a leader who has the ability to act in accordance with the principles and values and do not hesitate to make sacrifices in the struggle for greater 
interest. Such leaders do not expect flattery or praise, they also do not care about the criticism and condemnation. Throughout what was done in accordance with the principles and values and to accommodate the interests of greater Yag they will run.Leaders can not be alone in improving labor discipline teachers should also boost arising from within the teacher, namely the desire to remain citizens of the school, the desire to remain in school and the desire to perform tasks in the school well. Tersebutlah impulses that gave rise to the work commitment of teachers in schools which will also affect the teachers' work discipline.

\section{CONCLUSION}

Influence Authentic leadership principals to discipline teachers working in MI as the city of Cimahi significant and the effect moderate. In practical factors that lead to influence being the authentic leadership of the working discipline is not optimal principals in discipline or to set an example of discipline in schools is also a relationship between teachers and principals who were deemed to be limited to the relationship, the establishment of school vision still limited at the level of executive means only beebrapa the teacher involved when the purpose of the school is a common goal that must be agreed upon and built together, the value in schools that have not fully shared values also self-awareness principal in setting a good example in the discipline to be a factor that authentic leadership only effect being, whereas the biggest factor affecting the work discipline are some other factors like compensation.

\section{REFERENCES}

[1] Rachmawati, Tutik and Daryanto. (2013). Professional Teacher Performance Assessment and credit figures. Yogyakarta. Gava media

[2] Robie Awaludin S, Muhammad. (2015). Influence Performance And Discipline Work Principal Teacher Effectiveness Against Private School Quality Management Se-Bandung. Educational Administration Thesis
[3] Barizi, Ahmad and Idris Muhammad. (2010). Become a Master seed. Jogyakarta: Ar-Ruzz Media

[4] Naser Abdul. (2012). Analysis of Effect of Work Discipline Against Teacher Achievement in Students In Junior High School 1 Tanjung Bintang. Organization and Management Journal, Vol.2, No: 1 (1-9) March 2012. Pg. 1-9

[5] Naser Abdul. (2012). Analysis of Effect of Work Discipline Against Teacher Achievement in Students In Junior High School 1 Tanjung Bintang. Organization and Management Journal, Vol.2, No: 1 (1-9) March 2012. Pg. 1-9

[6] Rival, Veithzal. 2004. Human Resource Management for the Company. Jakarta: PT. King Grafindo Persada

[7] Andiyasari, andin and Ardiningtiyas Pitaloka. (2010). Authentic Leadership Perception And Work Engagement On Generation X \& Y in Indonesia. Paramadina University Journal Vol. 7 No. 2, June 2010 Special Edition. P. 271-388

[8] Wulan, Sarah. (2013). Discipline Relationship With Teacher Performance SMA in Three District of Depok. WIDYA Scientific Journals, Volume 1 Number 2 July-August 2013, p. 106-112

[9] Umi Masruroh, Faiz Thomas, and Lyna Latifah. (2012). Compensation Effect on Performance and Work Discipline Master of Economics Sma Negeri Brebes. Education Economic Analysis Journal (EEAJ) 1 (2) (2012). P. 1-7

[10] Avolio, B., Gardner, W., Walumbwa, F., \& May, D. (2004). Unlocking the mask: A look at the process by the which authentic leaders follower impact attitudes and behaviors. Leadership Quarterly, 15 (6), 801-823.

[11] Qian Ling, Fang Liu, and Xiaoyi Wu. (2016). Versus Authentic Servant Leadership: Assessing Effectiveness in China's Hospitality Industry. sagepub.com/journalsPermissions.nav. Cornell Hospitality Quarterly. P. 1-16

[12] Suharsaputra, Uhar. (2013). Become Master Yang Character. Bandung: Refika Aditama

[13] Armstrong, M (2009). Armstrong's Handbooks of human resource management practice 11th edition. London: Kogan Page

[14] Arita, Keke T. (2005). Compensation Work, Work Discipline Master and Teacher Performance Christian SMP BPK PENABUR Jakarta. Journal of Educational Sower - No.04 / Th.IV / July 2005. Pg. 1-16

[15]Ernawati and Marjono. (2007). Work Discipline Supervision Influence on Performance and Master. Human Resource Management Journal Vol. 2 No. December 1, 2007, p. 11-22

[16] Sukertiasih, Ni Komang. (2009). The Authentic Influence of Transformational Leadership on Job Satisfaction Guru Sma Saraswati Mataram. GaneÇ Swara Special Edition Vol. 33 December 2009. Pg. 59-66 